Article

\title{
Evaluation of the Antibacterial Material Production in the Fermentation of Bacillus amyloliquefaciens-9 from Whitespotted Bamboo Shark (Chiloscyllium plagiosum)
}

\author{
Wenjie Zhang ${ }^{1}$, Ling Wei ${ }^{1}$, Rong Xu ${ }^{1}$, Guodong Lin ${ }^{1}$, Huijie Xin ${ }^{1}$, Zhengbing Lv ${ }^{1}$, \\ Hong Qian ${ }^{1, *}$ and Hengbo Shi ${ }^{1,2, *(D)}$ \\ 1 Zhejiang provincial key Laboratory of Silkworm Bioreactor and Biomedicine, College of Life Sciences \\ and medicine, Zhejiang Sci-Tech University, Hangzhou 310018, China; zwj_67890@163.com (W.Z.); \\ 13361336708@163.com (L.W.); xurong20172020@163.com (R.X.); 15990051831@163.com (G.L.); \\ xinhuijie1994@163.com (H.X.); zhengbingl@126.com (Z.L.) \\ 2 College of Animal Science, Zhejiang University, Hangzhou 310015, China \\ * $\quad$ Correspondence: h.qian@novo-biotech.com (H.Q.); shihengbo@zstu.edu.cn (H.S.); Tel.: +86-571-8898-1341 (H.S.)
}

Received: 11 December 2019; Accepted: 13 February 2020; Published: 18 February 2020

Abstract: Bacillus amyloliquefaciens-9 (GBacillus-9), which is isolated from the intestinal tract of the white-spotted bamboo shark (Chiloscyllium plagiosum), can secrete potential antibacterial materials, such as $\beta-1,3-1,4$-glucanase and some antimicrobial peptides. However, the low fermentation production has hindered the development of GBacillus- 9 as biological additives. In this study, the Plackett-Burman design and response surface methodology were used to optimize the fermentation conditions in a shake flask to obtain a higher yield and antibacterial activity of GBacillus-9. On the basis of the data from medium screening, M9 medium was selected as the basic medium for fermentation. The data from the single-factor experiment showed that sucrose had the highest antibacterial activity among the 10 carbon sources. The Plackett-Burman design identified sucrose, $\mathrm{NH}_{4} \mathrm{Cl}$, and $\mathrm{MgSO}_{4}$ as the major variables altering antibacterial activity. The optimal concentrations of these compounds to enhance antibacterial activity were assessed using the central composite design. Data showed that sucrose, $\mathrm{NH}_{4} \mathrm{Cl}$, and $\mathrm{MgSO}_{4}$ had the highest antibacterial activities at concentrations of $64.8,1.84$, and $0.08 \mathrm{~g} \mathrm{~L}^{-1}$, respectively. The data also showed that the optimal fermentation conditions for the antibacterial material production of GBacillus-9 were as follows: Inoculum volume of $5 \%$, initial $\mathrm{pH}$ of 7.0 , temperature of $36{ }^{\circ} \mathrm{C}$, rotating speed of $180 \mathrm{rpm}$, and fermentation time of $10 \mathrm{~h}$. The optimal fermentation medium and conditions achieved to improve the yield of antibacterial materials for GBacillus-9 can enhance the process of developing biological additives derived from GBacillus-9.

Keywords: antibacterial materials; Bacillus amyloliquefaciens; whitespotted bamboo shark; biological additive

\section{Introduction}

The wide usage of antibiotics in the world has rapidly increased the risk of antibiotic-resistant pathogens. Many new and nonconventional anti-infective therapies have been developed and/or identified to solve this threat [1]. Marine microorganisms are regarded as major sources of antimicrobial agents [2]. Bacillus amyloliquefaciens, a widely distributed and environmentally friendly aerobic Gram-positive Bacillus bacterium, is rich in metabolites and can secrete bacteriostatic substances, such as lipopeptides [3,4] and glycosidases [5]. B. amyloliquefaciens has been used in animal feeding [6] or the therapy of plant diseases due to its ability to produce broad-spectrum antibacterial activity $[7,8]$. 
The B. amyloliquefaciens BTSS-3 isolated from a deep-sea shark (Centroscyllium fabricii) has shown antimicrobial activity against pathogenic bacteria, including Salmonella typhimurium, Proteus vulgaris, Clostridium perfringens, and Staphylococcus aureus [9]. Isolated from soil, B. amyloliquefaciens MET0908 is used to cure cucumber anthracnose [7]. B. amyloliquefaciens PPCB004 has inhibitory effects against the fungal pathogens of harvested citrus [8]. B. amyloliquefaciens US 573 is reported as a feeding additive that promotes animal nutrient absorption and feed conversion ratio [6].

The whitespotted bamboo shark (Chiloscyllium plagiosum) is a demersal cartilage fish distributed from the Indian Ocean to the Western Pacific Ocean. The bacteria in the shark, particularly those in the digestive tract, produce inhibitory compounds responsible for controlling the colonization of potential pathogens in fish [10,11]. B. amyloliquefaciens-9 (GBacillus-9, also named Bacillus sp. GFP-2), a strain of B. amyloliquefaciens, was isolated from the intestinal tract of the whitespotted bamboo shark (C. plagiosum) [12]. The antimicrobial peptides (AMPs) and $\beta-1,3-1,4-$ glucanase expressed in GBacillus-9 could partially contribute to inhibit Gram-negative/positive bacteria [12]. In vivo, GBacillus-9 improves immunity by promoting the lysozyme content of the skin mucosa in hybrid sturgeon (Acipenser sinensis), indicating GBacillus-9's potential as a feed additive for aquaculture farmed fish [13]. Furthermore, the data on Japanese eel support the idea of developing bacterial additives in fish raising by using GBacillus-9 [14]. All these data suggest that the antibacterial material in GBacillus-9 can be used as a "drug" in the fish farm, which can help decrease the use of antibiotics in agriculture.

However, the idea of developing a "drug" by using GBacillus-9 is hindered by its low antibacterial material production. The optimization of fermentation conditions will benefit the use of GBacillus-9. The single-factor experiment, Plackett-Burman (PB), and central composite designs (CCDs) [15-19] were used to optimize the fermentation conditions of GBacillus-9, achieve high antibacterial activity, and overcome the limited fermentation efficiency of GBacillus-9.

\section{Results}

\subsection{Effect of Different Culture Media and Main Ingredient Sources on Antibacterial Activity}

Seven basic media with different carbon and nitrogen sources were assessed for the GBacillus-9 culture to determine the culture medium with high efficiency. As shown in Figure 1a, GBacillus-9 had the highest antibacterial activities against Escherichia coli TG1 (TG1) and Bacillus subtilis BS168 (BS168) when cultured in M9 medium, followed by nutrient yeast beef glucose (NYBD), beef peptone yeast (BPY), nutrient agar (NA), and Luria-Bertani (LB) media. The use of yeast sucrose peptone (YSP) and yeast peptone glucose (YPG) media resulted in GBacillus-9's lowest antibacterial activity against TG1 and BS168. Thus, M9 medium was selected as the basic culture medium. The growth curve showed that a high GBacillus-9 density did not result in high antibacterial activity. No significant relationship between bacteriostatic activity and growth was observed.

Carbon and nitrogen sources have significant effects on cell metabolite activity [20]. In the current study, nine carbon sources in M9 medium were screened to culture GBacillus-9 (Figure 1b,c). The maximum antibacterial activity was detected when sucrose was used as the carbon source, followed by glucose, mannitol, and dextrin. The use of maltose, lactose, and soluble starch resulted in small inhibition zones. The addition of citric acid and xylose almost destroyed the antibacterial ability of GBacillus-9.

Seven nitrogen sources were assessed based on the antibacterial activity. As shown in Figure 1c, $\mathrm{NH}_{4} \mathrm{Cl}$, yeast extract, and peptone had similar antibacterial effects against TG1 and BS168. The addition of urea and beef cream led to the loss of antibacterial activity. $\mathrm{NH}_{4} \mathrm{Cl}$ was selected as the nitrogen source because of its advantages, such as low cost and source availability. 
(a)

(c)
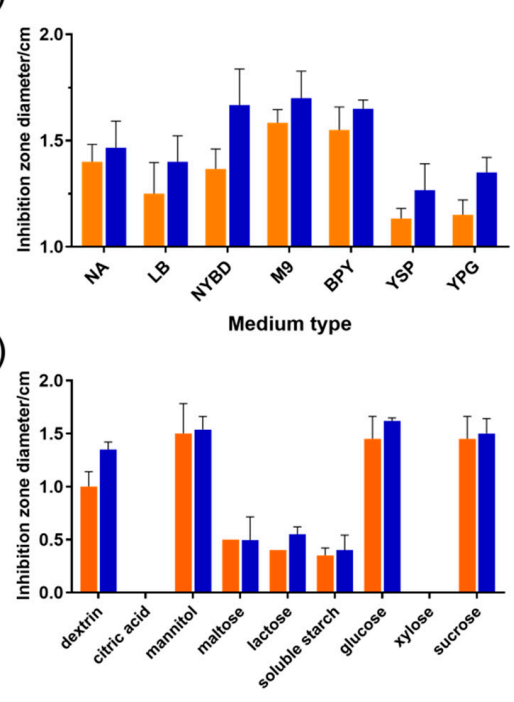

Carbon source (b)

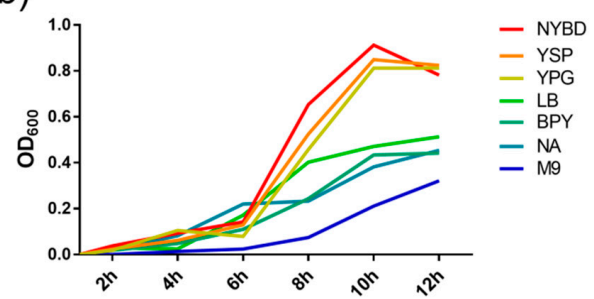

(d)

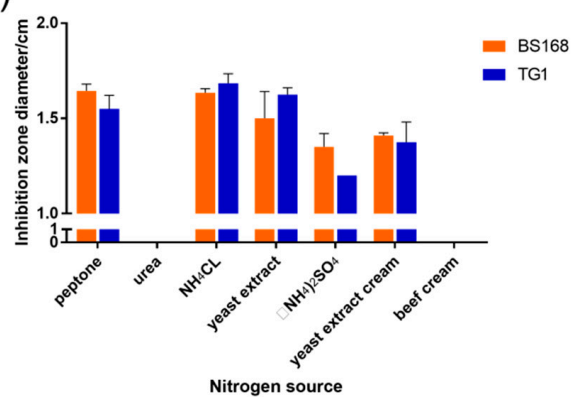

Figure 1. Effects of various media and main ingredient sources on antibacterial activity. (a) Effect of different media (nutrient agar (NA), Luria-Bertani (LB), nutrient yeast beef glucose (NYBD), M9, beef peptone yeast (BPY), yeast sucrose peptone (YSP), and yeast peptone glucose (YPG)) on the antibacterial activity of metabolites. TG1 and BS168 (representing the Gram-negative and Gram-positive bacteria, respectively) were used to detect antibacterial activity. The $\mathrm{Y}$ axis represents the diameter of the inhibition zone, indicating the antibacterial activity of metabolites. (b) Growth curves of GBacillus-9 in different media. Effects of (c) carbon and (d) nitrogen sources on the antibacterial activity of metabolites in M9 medium. The sources of carbon included dextrin, citric acid, mannitol, maltose, lactose, soluble starch, glucose, xylose, and sucrose. The sources of nitrogen included peptone, urea, $\mathrm{NH}_{4} \mathrm{Cl}$, yeast extract, $\left(\mathrm{NH}_{4}\right)_{2} \mathrm{SO}_{4}$, yeast extract cream, and beef cream.

\subsection{Determination of the Initial Concentration of Each Component in M9 Medium Using Single-Factor} Experiment Design

The component in M9 medium was altered to determine the antibacterial activity of the GBacillus-9 strain in the modified M9 medium. As shown in Figure 2, increasing each component increased the antibacterial activity of GBacillus-9. The optimum concentrations of sucrose, $\mathrm{Na}_{2} \mathrm{HPO}_{4}, \mathrm{KH}_{2} \mathrm{PO}_{4}$, $\mathrm{NH}_{4} \mathrm{Cl}, \mathrm{MgSO}_{4}$, and $\mathrm{NaCl}$ were at $30,8.5,3.0,1.0,0.5$, and $0.5 \mathrm{~g} \mathrm{~L}^{-1}$, respectively.

(a)

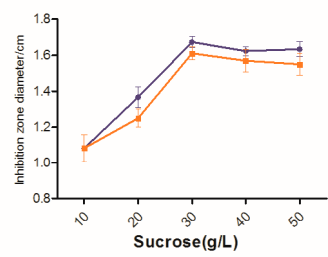

(d)

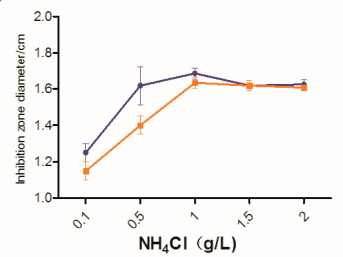

(b)

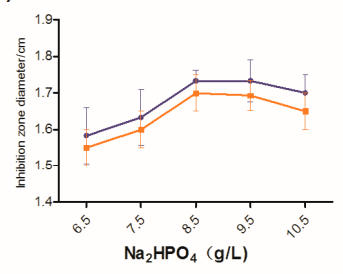

(e)

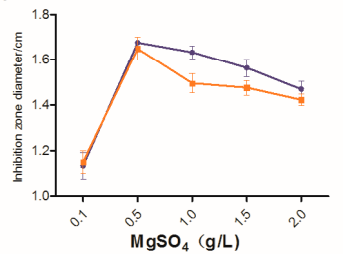

(c)

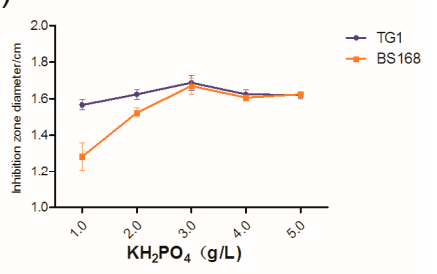

(f)

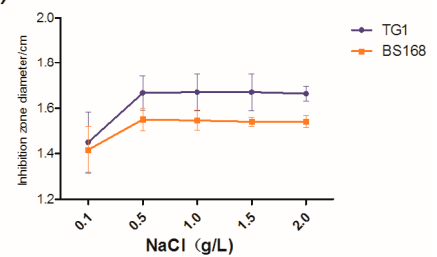

Figure 2. Optimum concentrations of Sucrose (a), $\mathrm{Na}_{2} \mathrm{HPO}_{4}(\mathbf{b}), \mathrm{KH}_{2} \mathrm{PO}_{4}(\mathbf{c}), \mathrm{NH}_{4} \mathrm{Cl}$ (d), $\mathrm{MgSO}_{4}(\mathbf{e})$, and $\mathrm{NaCl}(\mathbf{f})$ in $\mathrm{M} 9$ medium. 


\subsection{Sucrose, $\mathrm{NH}_{4} \mathrm{Cl}$, and $\mathrm{MgSO}_{4}$ as Key Factors Affecting GBacillus-9 Culture}

The results of various cultures with antibacterial activity are shown in Table 6. After analyzing the samples from culture media, the mean diameters of the inhibition zones in all samples were measured. All data were used as dependent variables Y1 (mean inhibition zone diameter of TG1) and Y2 (mean inhibition zone diameter of BS168) in the PB design.

The polynomial model, which predicted the inhibition zone diameter of TG1 obtained from PB regression analysis, was expressed in terms of coded factors as

$$
\mathrm{Y} 1(\mathrm{~cm})=1.362+0.121^{*} \mathrm{~A}+0.030^{*} \mathrm{~B}+0.045^{*} \mathrm{C}+0.1203^{*} \mathrm{D}+0.004^{*} \mathrm{E}-0.072^{*} \mathrm{~F} \text {. }
$$

The second response value analyzed was the inhibition zone diameter of BS168. The polynomial model, which predicted the inhibition zone diameter of BS168 obtained from PB regression analysis, was expressed in terms of coded factors as

$$
\mathrm{Y} 2(\mathrm{~cm})=1.416+0.184^{*} \mathrm{~A}+0.134^{*} \mathrm{~B}+0.016^{*} \mathrm{C}+0.124^{*} \mathrm{D}+0.058^{*} \mathrm{E}-0.070^{*} \mathrm{~F} .
$$

The analysis of variance (ANOVA) was applied to test the availability of PB design for the responses $\mathrm{Y} 1$ and $\mathrm{Y} 2$. Results are shown in Tables 1 and 2. The analysis of $P$-values and the Pareto chart (Figure 3) showed that among the variables tested, sucrose, $\mathrm{NH}_{4} \mathrm{Cl}$, and $\mathrm{MgSO}_{4}$ had significant $(p<0.05)$ effects on the inhibition zone diameter of TG1 (Table 1, Figure 3a), whereas only sucrose had a significant $(p<0.05)$ effect on the inhibition zone diameter of BS168 (Table 2, Figure $3 b$ ).

Table 1. Analysis of variance (ANOVA) for the regression model of the inhibition zone of TG1 using the Plackett-Burman design.

\begin{tabular}{ccccc}
\hline Variable & Coefficient Estimate & SE Coefficient & T Value & $p$ Value \\
\hline constant & 1.362 & 0.024 & 55.900 & 0.000 \\
sucrose & 0.121 & 0.024 & 4.980 & $0.004{ }^{*}$ \\
$\mathrm{Na}_{2} \mathrm{HPO}_{4}$ & 0.030 & 0.024 & 1.220 & 0.277 \\
$\mathrm{KH}_{2} \mathrm{PO}_{4}$ & 0.045 & 0.024 & 1.860 & 0.122 \\
$\mathrm{NH}_{4} \mathrm{Cl}$ & 0.120 & 0.024 & 4.940 & $0.004 *$ \\
$\mathrm{NaCl}$ & 0.004 & 0.024 & 0.150 & 0.888 \\
$\mathrm{MgSO}_{4}$ & -0.072 & 0.026 & -2.730 & $0.041^{*}$ \\
\hline \multicolumn{5}{c}{$p<0.05$, Significance was declared when $p<0.05}$.
\end{tabular}

Table 2. Analysis of variance (ANOVA) for the regression model of the inhibition zone of BS168 using the Plackett-Burman design.

\begin{tabular}{ccccc}
\hline Variable & Coefficient Estimate & SE Coefficient & T Value & $p$ Value \\
\hline constant & 1.416 & 0.063 & 22.230 & 0.000 \\
sucrose & 0.184 & 0.063 & 2.890 & $0.034^{*}$ \\
$\mathrm{Na}_{2} \mathrm{HPO}_{4}$ & 0.134 & 0.063 & 2.110 & 0.814 \\
$\mathrm{KH}_{2} \mathrm{PO}_{4}$ & 0.016 & 0.063 & 0.250 & 0.814 \\
$\mathrm{NH}_{4} \mathrm{Cl}$ & 0.124 & 0.063 & 1.950 & 0.109 \\
$\mathrm{NaCl}$ & 0.058 & 0.063 & 0.900 & 0.408 \\
$\mathrm{MgSO}_{4}$ & -0.070 & 0.068 & -1.020 & 0.335 \\
\hline & $* p<0.05$, Significance was declared when $p<0.05$.
\end{tabular}

(a)

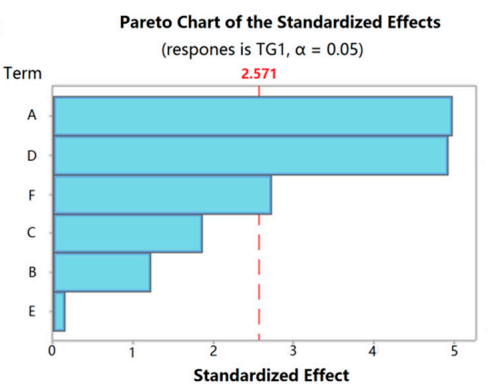

(b)

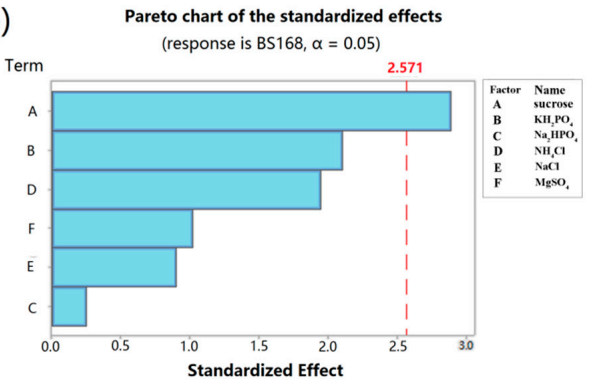

Figure 3. Pareto chart of the standardized effects: (a) Response is TG1; (b) response is BS 168; 


\subsection{Optimization of Fermentation Conditions by Using CCD}

CCD was utilized to assess the influence of three individual factors, namely, sucrose (A), $\mathrm{NH}_{4} \mathrm{Cl}(\mathrm{B})$, and $\mathrm{MgSO}_{4}(\mathrm{C})$, along with their interaction effects on the yield of antibacterial materials. The experimental and predicted values of the inhibition zone diameter under different treatment conditions are shown in Table 8. The predicted responses Y3 (TG1) and Y4 (BS168) for inhibition zone diameter in terms of coded factors are expressed as follows:

$$
\begin{gathered}
\mathrm{Y} 3(\mathrm{~cm})=1.4307+0.11103^{*} \mathrm{~A}+0.06766^{*} \mathrm{~B}-0.06860^{*} \mathrm{C}+0.02349 \mathrm{~A}^{2}-0.02070^{*} \mathrm{~B}^{2} \\
-0.02070^{*} \mathrm{C}^{2}+0.0362^{*} \mathrm{AB}-0.0263^{*} \mathrm{AC}-0.0338^{*} \mathrm{BC} . \\
\mathrm{Y} 4(\mathrm{~cm})=1.44359+0.09386^{*} \mathrm{~A}+0.05295^{*} \mathrm{~B}-0.05951^{*} \mathrm{C}+0.00069 \mathrm{~A}^{2}-0.02582 \mathrm{~B}^{2} \\
-0.02406 \mathrm{C}^{2}+0.02375^{*} \mathrm{AB}-0.00625^{*} \mathrm{AC}-0.02875^{*} \mathrm{BC} .
\end{gathered}
$$

where $\mathrm{Y} 3$ and $\mathrm{Y} 4$ are the response variables of inhibition zone diameter, and $\mathrm{A}, \mathrm{B}$, and $\mathrm{C}$ are independent variables in coded units. The regression model was statistically detected using the F-test, and ANOVA was utilized to evaluate the significance and adequacy of the model [21].

As shown in Tables 3 and 4, the $p$-values obtained using ANOVA and the F-test were less than 0.05 , demonstrating that the model term was significant $(p<0.05)$. Tables 3 and 4 showed that the coefficients for $\mathrm{A}, \mathrm{B}$, and $\mathrm{C}$ were extremely significant $(p<0.05)$, indicating that sucrose, $\mathrm{NH}_{4} \mathrm{Cl}$, and $\mathrm{MgSO}_{4}$ had a remarkable influence on the antibacterial production of GBacillus-9. The model was significant with a very low $p$-value $<0.01$ ( $p$-value Probability $>\mathrm{F}$ ). The $\mathrm{R}^{2}$ and adjusted $\mathrm{R}^{2}$ values for TG1 (0.9748 and 0.9522, respectively) and BS168 (0.9773 and 0.9569, respectively) were close to 1 , indicating the high efficacy of Equations (3) and (4) [22].

Table 3. Analysis of CCD test results for TG1.

\begin{tabular}{cccccc}
\hline Source & Degree of Freedom & Adj SS & Adj MS & Value & $p$-Value \\
\hline Model & 9 & 0.34 & 0.038 & 43.02 & $<0.0001^{\#}$ \\
\hline A & 1 & 0.17 & 0.17 & 190.38 & $<0.0001^{\#}$ \\
B & 1 & 0.063 & 0.063 & 70.70 & $<0.0001^{\#}$ \\
C & 1 & 0.064 & 0.064 & 72.66 & $<0.0001^{\#}$ \\
A2 & 1 & 0.011 & 0.011 & 11.89 & $0.0062^{\#}$ \\
B2 & 1 & $5.512 \times 10^{-3}$ & $5.512 \times 10^{-3}$ & 6.23 & $0.0316^{\#}$ \\
C2 & 1 & $9.112 \times 10^{-3}$ & $9.112 \times 10^{-3}$ & 10.30 & $0.0093^{\#}$ \\
$\mathrm{~A}^{*} \mathrm{~B}$ & 1 & $7.953 \times 10^{-3}$ & $7.953 \times 10^{-3}$ & 8.99 & $0.0134^{\#}$ \\
$\mathrm{~A}^{*} \mathrm{C}$ & 1 & $6.177 \times 10^{-3}$ & $6.177 \times 10^{-3}$ & 6.98 & $0.0246^{\#}$ \\
$\mathrm{~B}^{*} \mathrm{C}$ & 1 & $6.177 \times 10^{-3}$ & $6.177 \times 10^{-3}$ & 6.98 & $0.00246^{\#}$ \\
Residual & 10 & $8.844 \times 10^{-3}$ & $8.844 \times 10^{-4}$ & & $<0.0004^{\#}$ \\
Lack of fit & 5 & $8.644 \times 10^{-3}$ & $1.729 \times 10^{-3}$ & 43.22 & \\
Pure error & 5 & $2.000 \times 10^{-4}$ & $4.000 \times 10^{-5}$ & & \\
Cor Total & 19 & 0.35 & & \\
\hline
\end{tabular}

Table 4. Analysis of CCD test results for BS168.

\begin{tabular}{cccccc}
\hline Source & Degree of Freedom & Adj SS & Adj MS & Value & $p$-Value \\
\hline Model & 9 & 0.24 & 0.026 & 47.82 & $<0.0001^{\#}$ \\
\hline A & 1 & 0.12 & 0.12 & 220.20 & $<0.0001^{\#}$ \\
B & 1 & 0.038 & 0.038 & 70.09 & $<0.0001^{\#}$ \\
C & 1 & 0.048 & 0.048 & 88.52 & $<0.0001^{\#}$ \\
A2 & 1 & $4.513 \times 10^{-3}$ & $4.513 \times 10^{-3}$ & 8.26 & $0.0166^{\#}$ \\
B2 & 1 & $3.125 \times 10^{-4}$ & $3.125 \times 10^{-4}$ & 0.57 & 0.4669 \\
C2 & 1 & $6.612 \times 10^{-3}$ & $6.612 \times 10^{-3}$ & 12.10 & 0.0059 \\
$\mathrm{~A}^{*} \mathrm{~B}$ & 1 & $6.905 \times 10^{-6}$ & $6.905 \times 10^{-6}$ & 0.013 & $0.9127^{\#}$ \\
$\mathrm{~A}^{*} \mathrm{C}$ & 1 & $9.611 \times 10^{-3}$ & $9.611 \times 10^{-3}$ & 17.59 & $0.0018^{\#}$ \\
$\mathrm{~B}^{*} \mathrm{C}$ & 1 & $8.340 \times 10^{-3}$ & $8.340 \times 10^{-3}$ & 15.26 & $0.0029^{\#}$ \\
Residual & 10 & $5.464 \times 10^{-3}$ & $5.464 \times 10^{-4}$ & & 0.4385 \\
Lack of fit & 5 & $2.930 \times 10^{-3}$ & $5.861 \times 10^{-4}$ & 1.16 & \\
Pure error & 5 & $2.533 \times 10^{-3}$ & $5.067 \times 10^{-4}$ & & \\
Cor Total & 19 & 0.24 & & &
\end{tabular}


The three-dimensional response surfaces and contour plots illustrated in Figure 4 depict the interactions of sucrose, $\mathrm{NH}_{4} \mathrm{Cl}$, and $\mathrm{MgSO}_{4}$ on antibacterial material yield by using TG1 and BS168 as substrates $[23,24]$. These results also directly show the response over a region of independent variables and the relationship between the experimental levels of each factor. Figure 4a reveals the effects of sucrose and $\mathrm{NH}_{4} \mathrm{Cl}$ on the antibacterial material yield of GBacillus-9, indicating that the inhibition zone increased upon increasing sucrose and $\mathrm{NH}_{4} \mathrm{Cl}$. The maximum inhibition zone diameter was observed when the concentrations of sucrose and $\mathrm{NH}_{4} \mathrm{Cl}$ were at 64.8 and $1.84 \mathrm{~g} \mathrm{~L}^{-1}$, respectively. Subsequently, the inhibition zone diameter of TG1 declined with the increase in sucrose and $\mathrm{NH}_{4} \mathrm{Cl}$ concentrations. Increasing the concentration of $\mathrm{MgSO}_{4}$ to more than $0.08 \mathrm{~g} \mathrm{~L}^{-1}$ resulted in a decreased inhibition zone diameter. The effect of $\mathrm{MgSO}_{4}$ on inhibition zone diameter is displayed in Figure $4 \mathrm{c}$, which had a trend similar to those in Figure 4a,b. The inhibition zone diameter of BS168 was smaller than that of TG1 under the same culture medium, as shown in Figure $4 \mathrm{~d}-\mathrm{f}$, but a similar antibacterial effect trend was observed in Figure $4 \mathrm{a}-\mathrm{c}$. Finally, the optimal concentrations of sucrose, $\mathrm{NH}_{4} \mathrm{Cl}$, and $\mathrm{MgSO}_{4}$ in the culture medium for GBacillus-9 were $64.8,1.84$, and $0.08 \mathrm{~g} \mathrm{~L}^{-1}$, respectively. Under the optimum conditions, the predicted maximum diameters of TG1 and BS168 inhibition zones were 1.93 and $1.82 \mathrm{~cm}$, respectively.

(a)

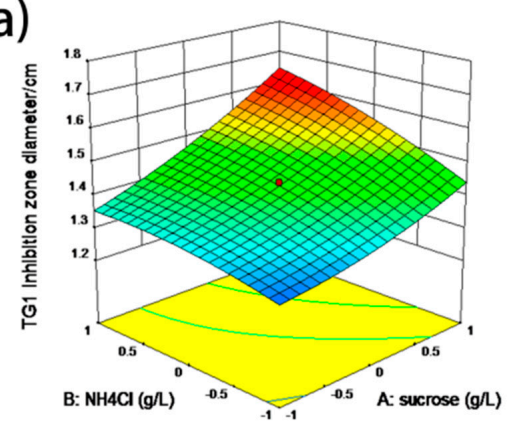

(b)

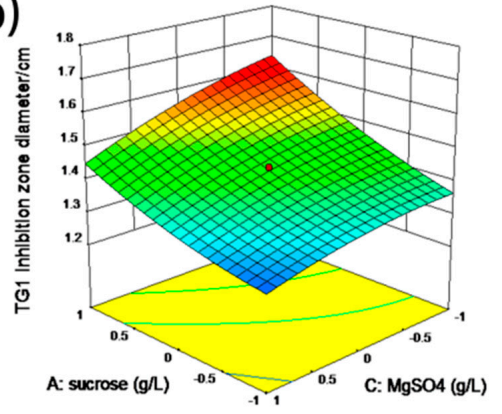

(c)

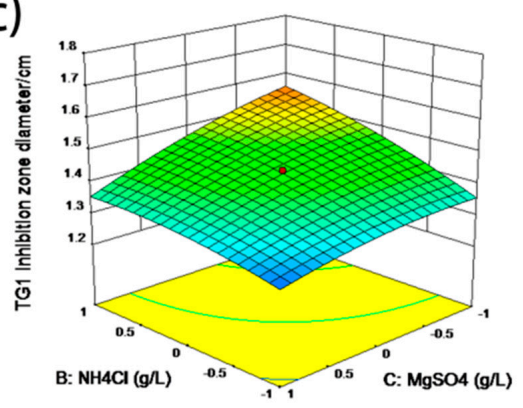

(d)

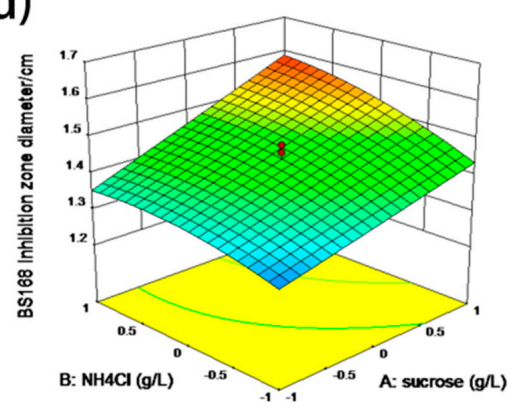

(e)

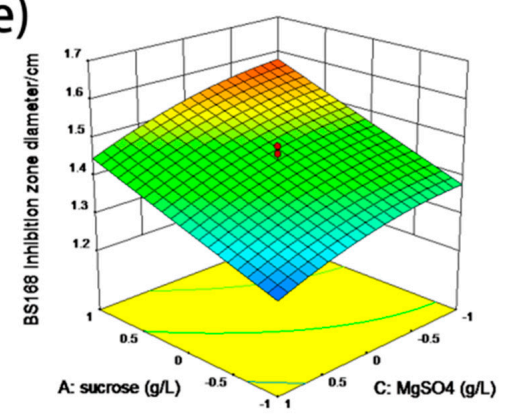

(f)

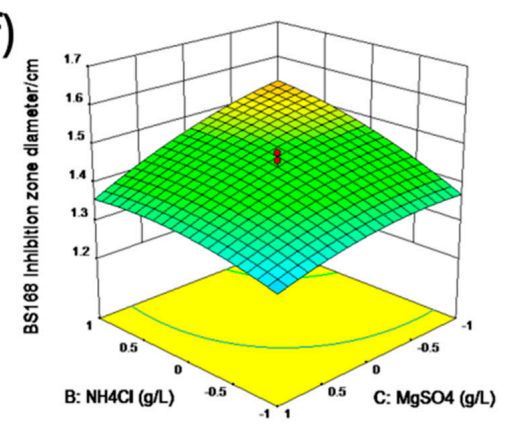

Figure 4. Response surface curves of the inhibition zone diameters of TG1 and BS168 by using the media cultured with GBacillus-9. (a) and (d): Interaction between sucrose and $\mathrm{NH}_{4} \mathrm{Cl}$. (b) and (e): Interaction between sucrose and $\mathrm{MgSO}_{4}$. (c) and (f): Interaction between $\mathrm{NH}_{4} \mathrm{Cl}$ and $\mathrm{MgSO}_{4}$. The standard concentrations of $\mathrm{Na}_{2} \mathrm{HPO}_{4}, \mathrm{KH}_{2} \mathrm{PO}_{4}$, and $\mathrm{NaCl}$ used in the experiment were 8.5, 3, and $0.5 \mathrm{~g} \mathrm{~L}^{-1}$, respectively. 


\subsection{Optimization of Fermentation Parameters}

The fermentation time, temperature, inoculum volume, initial $\mathrm{pH}$, and rotation speed were also assessed to further explore the optimal fermentation conditions of GBacillus-9. As shown in Figure 5, the inhibition zone diameter of anti-TG1 and anti-BS168 showed a similar pattern, that is, the inhibition zone diameter increased with fermentation time, temperature, inoculum volume, initial $\mathrm{pH}$, and rotation speed. The maximum inhibition zone diameters of anti-TG1 and anti-BS168 were achieved when the fermentation time, temperature, inoculum volume, initial $\mathrm{pH}$, and rotation speed were $10 \mathrm{~h}$, $36{ }^{\circ} \mathrm{C}, 5 \%, 7.0$, and $180 \mathrm{rpm}$, respectively. Subsequently, the inhibition zone diameter of TG1 declined with fermentation time, temperature, inoculum volume, initial $\mathrm{pH}$, and rotation speed.

(a)

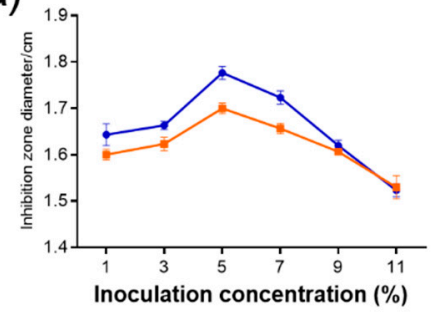

(b)

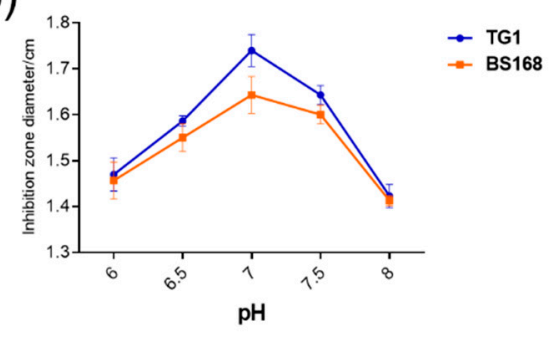

(c)

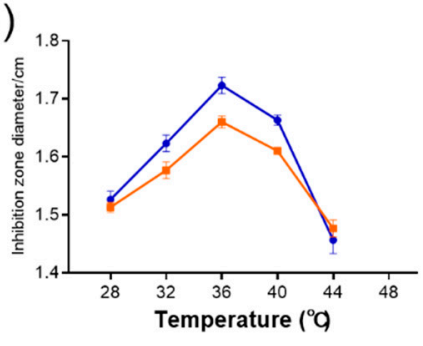

(d)

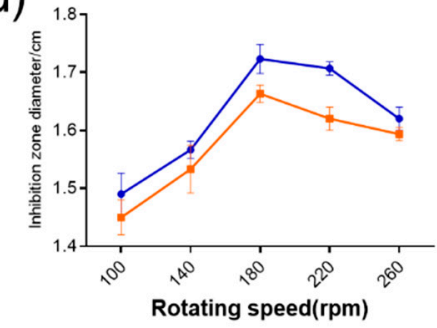

(e)

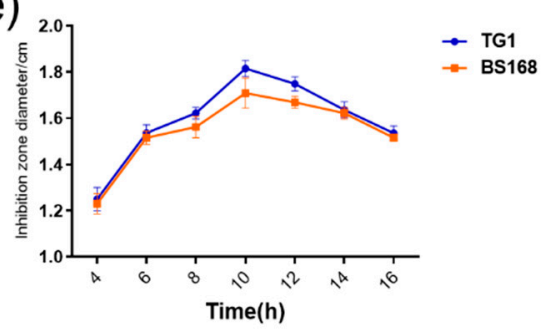

Figure 5. Effect of fermentation parameters ((a): Inoculation concentration, (b): $\mathrm{pH},(\mathbf{c})$ : Temperature, (d): Rotating speed, and (e): Time) on the antibacterial activity of metabolites.

\subsection{Fermentation Using a 20 L Bioreactor}

The optimized fermentation conditions (inoculum volume of $5 \%$, initial $\mathrm{pH}$ of 7.0 , rotating speed of $180 \mathrm{rpm}$, and temperature of $36^{\circ} \mathrm{C}$ ) was verified using a $20 \mathrm{~L}$ bioreactor to determine whether the results predicted by the model were consistent with the actual results. The fermentation product was subjected to an antibacterial activity test. Figure 6 showed that the culture supernatant of GBacillus- 9 had inhibition zone diameters of 1.82 and $1.78 \mathrm{~cm}$ for TG1 and BS168, respectively. These results were in agreement with the predicted values.

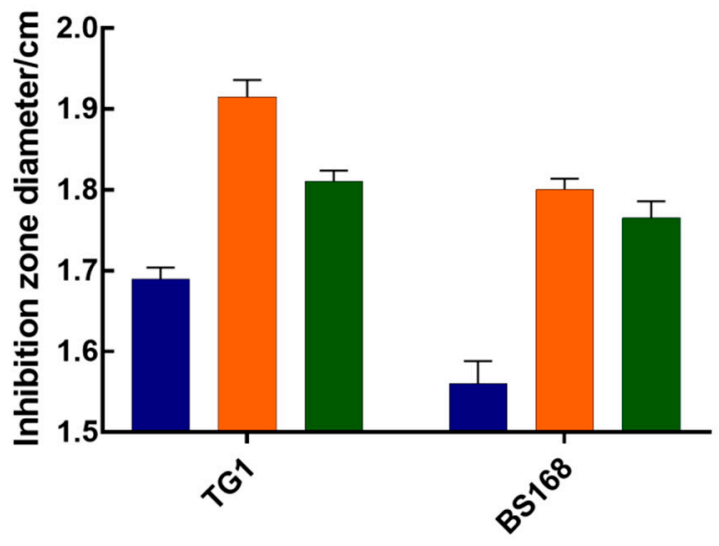

before optimization
optimization
Fermentation in 20-L Bioreactor

Figure 6. Validation of the optimal fermentation conditions of GBacillus-9 in 20 L bioreactor. 


\section{Discussion}

The marine environment is a largely untapped source for the isolation of new microorganisms with the potential to produce bioactive compounds [25]. The host organism synthesizes bioactive compounds as primary or secondary metabolites to protect or maintain homeostasis [26]. GBacillus-9, which is isolated from the intestine of the whitespotted bamboo shark, has shown potential in the development of biological additives [12,13]. Thus, investigating the optimal fermentation conditions with high efficiency and low cost is an important strategy to develop biological additives. In the current study, PB design and CCD were applied to evaluate the fermentation efficiency of GBacillus-9 through various media, and the results showed efficient fermentation parameters with the improved yield of the antibacterial material in GBacillus-9.

The GBacillus-9 strain has shown a broad-spectrum antibacterial activity on Gram-negative and Gram-positive bacteria [12]. In the current study, TG1 and BS168, which represented the Gram-negative and the Gram-positive bacteria, respectively, were used to detect antibacterial activity. The current data showed that the antibacterial material secreted by GBacillus-9 had a stronger activity against Gram-negative bacteria (TG1) than Gram-positive bacteria (BS168), which agreed with the fact that AMPs blocked the growth of Gram-negative bacteria by entering the membrane and disrupting the local electrostatic fields [27]. The weak activity of GBacillus-9 against Gram-positive bacteria may be due to the inherent properties of Gram-positive bacteria, which contain more peptidoglycan than Gram-negative bacteria. The peptidoglycan hinders the entry of AMPs into cells, thereby reducing antibacterial activity $[28,29]$.

The medium most beneficial to the production of antibacterial substances in GBacillus-9 was obtained by screening different media. No evident relationship was found between the bacteriostatic activity and the number of bacteria. The increased antibacterial activity may be caused by a secondary metabolite secreted by GBacillus-9.

There have been many reports on the antibacterial substances of $B$. subtilis, which mainly achieved the antibacterial effect by secreting peptides, lipids, and other substances [30,31]. Most of the $B$. subtilis strains capable of secreting antibacterial substances are isolated from soil and plants [6-8]. However, it is still relatively rare to isolate Bacillus subtilis in the ocean, and the GBacillus-9 culture medium isolated in the present study has a strong antibacterial activity against Gram-positive and Gram-negative bacteria. Moreover, after optimizing the culture medium, the high activity remained even after spray drying, which was conducive to large-scale market applications.

Carbon and nitrogen sources play an important role in the growth and cellular metabolism of bacteria [32,33]. Although these carbon sources resulted in the similar OD value of GBacillus-9, sucrose, glucose, and mannitol had the highest antibacterial activity. The various antibacterial material products with different carbon sources agreed with the suggestion that high cell weight does not always lead to the increased production of antibacterial substances $[34,35]$. Sucrose was selected because it was cheaper than glucose and mannitol. In the present study, the effects of nine carbon sources and seven nitrogen sources on the secretion of GBacillus-9 antibacterial substances were screened. Unsurprisingly, sucrose and $\mathrm{NH}_{4} \mathrm{Cl}$ were identified as the most important factors with respect to inhibition zone diameters of anti-TG1 and anti-BS168. Both sources met the bacterial mass and the production of antibacterial substances.

The PB design is a screening procedure that identifies essential variables in the production of a response parameter by analyzing the main effects, which allow multiple factors to be screened within one experiment. This design has been well used in assessing the nutritional requirements of bacteria to optimize enzyme production [36-38]. In the present study, sucrose, $\mathrm{NH}_{4} \mathrm{Cl}$, and $\mathrm{MgSO}_{4}$ were identified as three key factors affecting the yield of anti-TG1. However, only sucrose was identified as the key factor affecting the yield of anti-BS168. This difference was attributed to the intrinsic characteristics, e.g., the composition of cytoderm, and of Gram-positive and Gram-negative bacteria. 
The increase in sucrose concentration increased the antibacterial activity of GBacillus-9, suggesting an increased production of bacteria when the concentration of sucrose was higher than $46.8 \mathrm{~g} \mathrm{~L}^{-1}$. The reason for using sucrose at $46.8 \mathrm{~g} \mathrm{~L}^{-1}$ in the culture medium was to avoid the viscosity caused by the higher concentration of sucrose in the subsequent spray drying for bacterial preparation [39]. Furthermore, a high concentration of $\mathrm{MgSO}_{4}$ inhibited the growth of GBacillus-9.

Aside from the cultured medium, the fermentation process also greatly affected the production. Moreover, $\mathrm{pH}$ can affect the cellular enzyme activity and the stability of microbial cell membranes, altering membrane permeability and nutrient absorption [40-42]. Additionally, inoculation affects the growth of microorganisms and the accumulation of metabolites. Excessive inoculation accelerates the consumption of the medium, whereas low-inoculum cell concentrations prolong the log phase $[43,44]$, both of which reduce the efficiency of fermentation. Besides, culture temperature, rotation speed, and culture time affect the secretion after fermentation in different degrees [45]. In the present study, the optimal inoculum volume, temperature, rotation speed, and initial pH for GBacillus- 9 were $5 \%(\mathrm{v} / \mathrm{v})$, $36{ }^{\circ} \mathrm{C}, 180 \mathrm{rpm}$, and 7.0, respectively, which were consistent with those of other B. amyloliquefaciens strains $[46,47]$.

The limitation of the present study was that the antibacterial materials secreted by GBacillus- 9 were not completely addressed. However, our previous data showed that $\beta-1,3-1,4$-glucanase and the antimicrobial peptides secreted by GBacillus-9 contributed to its antimicrobial activity [12]. The detection of $\beta-1,3-1,4$-glucanase in the crude proteins from GBacillus-9 culture supernatant confirmed that GBacillus-9 could indeed express $\beta-1,3-1,4$-glucanase. Furthermore, the antimicrobial activity of purified recombinant $\beta-1,3-1,4$-glucanase cloned from the GBacillus-9 genome suggests that $\beta-1,3-1,4$-glucanase is a factor contributing to antimicrobial activity [12]. The genome data indicated that GBacillus-9 contained genes encoding LCI (a 47 residue cationic antimicrobial peptide), yellowfin tuna GAPDH-related antimicrobial peptide, and human GAPDH-related AMPs [12]. Beyond the potential AMPs, metabolites, such as difficidin, bacillibactin, bacilysin, surfactin, butirosin, macrolactin, bacillaene, and fengycin, and bacteriocins have been predicted in the genome of GBacillus-9 [12], which may contribute to the antibacterial role. Collectively, these results suggest that the inhibitory effects of GBacillus-9 on Gram-negative/positive bacteria might be dependent on complex metabolites. More experiments are needed to address the antibacterial materials in GBacillus-9 in the future.

The inhibition zone diameter of the anti-TG1 and anti-BS168 in the optimal culture medium reached 1.82 and $1.78 \mathrm{~cm}$, respectively, which were significantly improved compared to that in the LB medium. The finding that the bacteriostatic test of GBacillus-9 with $20 \mathrm{~L}$ was consistent with the predicted regression model suggested success in using the response surface method to improve the fermentation efficiency and that the factor effects were real.

In the present study, optimization studies using PB and response surface methodology identified the optimal nutritional factors involved in the maximal production of antibacterial compounds from GBacillus-9, supporting a fermenter to obtain a large number of GBacillus-9. Thus, two necessary market application requirements for the easily obtained and low-cost development of a "drug" were met. These data can enhance the process of developing biological additives. In addition, results showed the optimal fermentation time, temperature, inoculum volume, initial $\mathrm{pH}$, and rotation speed for GBacillus-9. However, the antibacterial material of GBacillus-9 and specific mechanism behind its biological activity remain unknown. Hence, further research is required.

\section{Materials and Methods}

\subsection{Strain and Media}

B. amyloliquefaciens-9 (GBacillus-9; CGMCC number: 13337, accession number: CP021011) [12] was isolated from the intestinal tract of $C$. plagiosum, which can secrete a variety of digestive enzymes to inhibit the growth of pathogenic bacteria. Seven different synthetic media were screened to improve the antimicrobial substance production of GBacillus-9. The media included LB (10 g L ${ }^{-1}$ peptone, 
$10 \mathrm{~g} \mathrm{~L}^{-1} \mathrm{NaCl}$, and $5 \mathrm{~g} \mathrm{~L}^{-1}$ yeast extract), BPY $\left(5 \mathrm{gL}^{-1}\right.$ glucose, $1 \mathrm{~g} \mathrm{~L}^{-1}$ peptone, $5 \mathrm{~g} \mathrm{~L}^{-1}$ beef extract, $5 \mathrm{~g} \mathrm{~L}^{-1} \mathrm{NaCl}$, and $5 \mathrm{~g} \mathrm{~L}^{-1}$ yeast extract), NYBD $\left(8 \mathrm{~g} \mathrm{~L}^{-1}\right.$ beef extract, $5 \mathrm{~g} \mathrm{~L}^{-1}$ yeast extract, and $10 \mathrm{~g} \mathrm{~L}^{-1}$ glucose), NA (10 g L ${ }^{-1}$ peptone, $2.5 \mathrm{~g} \mathrm{~L}^{-1}$ glucose, and $3 \mathrm{~g} \mathrm{~L}^{-1}$ beef extract), YPG $\left(10 \mathrm{~g} \mathrm{~L}^{-1}\right.$ yeast extract, $20 \mathrm{~g} \mathrm{~L}^{-1}$ peptone, and $20 \mathrm{~g} \mathrm{~L}^{-1}$ glucose $), \mathrm{YSP}\left(5 \mathrm{~g} \mathrm{~L}^{-1}\right.$ yeast extract, $20 \mathrm{~g} \mathrm{~L}^{-1}$ sucrose, and $10 \mathrm{~g} \mathrm{~L}^{-1}$ peptone), and M9 (20 g L $\mathrm{g}^{-1}$ glucose, $8.5 \mathrm{~g} \mathrm{~L}^{-1} \mathrm{Na}_{2} \mathrm{HPO}_{4}, 3 \mathrm{~g} \mathrm{~L}^{-1} \mathrm{KH}_{2} \mathrm{PO}_{4}, 1 \mathrm{~g} \mathrm{~L}^{-1} \mathrm{NH}_{4} \mathrm{Cl}$, $0.5 \mathrm{~g} \mathrm{~L}^{-1} \mathrm{NaCl}$, and $0.5 \mathrm{~g} \mathrm{~L}^{-1} \mathrm{MgSO}_{4}$ ) media. The medium $\mathrm{pH}$ was adjusted to 7.0-7.2. GBacillus-9 was cultured for $12 \mathrm{~h}$ at $37^{\circ} \mathrm{C}$ with rotary shaking at $220 \mathrm{rpm}$ in different culture media, and the antimicrobial ability was detected. All the experiments were performed at least thrice.

\subsection{Detection of Antimicrobial Activity}

The antimicrobial ability of GBacillus-9 was identified using the inhibition zone method [12]. The Gram-positive bacterium BS168 and the Gram-negative bacterium TG1 were used as test strains and inoculated into LB solid medium at $1 \%$ of the total amount. After solidification, an Oxford cup was placed on the medium and added with a volume of $250 \mu \mathrm{L}$ fermentation product. The sample was diluted 1000 times by using $50 \mathrm{mg} / \mathrm{mL}$ ampicillin (Amp) as the positive control and the blank medium as the negative control. After incubation for $10 \mathrm{~h}$ in a $37^{\circ} \mathrm{C}$ incubator, the diameter of the inhibition zone (accurate to $0.1 \mathrm{~mm}$ ) was measured.

\subsection{Effect of Carbon and Nitrogen Sources}

GBacillus-9 was grown in M9 basal liquid medium. The basal liquid medium was supplemented separately with carbon sources $\left(20 \mathrm{~g} \mathrm{~L}^{-1}\right)$, namely, glucose, xylose, sucrose, dextrin, citric acid, mannitol, maltose, lactose, and soluble starch. In the case of nitrogen $\left(1 \mathrm{~g} \mathrm{~L}^{-1}\right)$, various nitrogen sources, namely, peptone, urea, $\mathrm{NH}_{4} \mathrm{Cl}$, yeast extract, $\left(\mathrm{NH}_{4}\right)_{2} \mathrm{SO}_{4}$, yeast extract cream, and beef cream, were supplemented. GBacillus- 9 was cultured at $37^{\circ} \mathrm{C}$ with rotary shaking at $220 \mathrm{rpm}$ in different culture media and incubated for $10 \mathrm{~h}$ at $37^{\circ} \mathrm{C}$. The antimicrobial ability was detected. All the experiments were performed at least thrice.

\subsection{Single-Factor Experiment Design}

The experiments were carried out by varying one condition at a time [48]. First, the carbon source (sucrose) was set to five concentration gradients (10-50 $\left.\mathrm{g} \mathrm{L}^{-1}\right)$, and GBacillus-9 was cultured in M9 culture media for $10 \mathrm{~h}$ at $37^{\circ} \mathrm{C}$. Next, the antimicrobial ability was detected using the inhibition zone method to find the optimal concentration of the carbon source. For $\mathrm{NH}_{4} \mathrm{Cl}$, the same $\mathrm{M} 9$ basal liquid medium was employed, but the $\mathrm{NH}_{4} \mathrm{Cl}$ was adjusted to a concentration of $0.1-2.0 \mathrm{~g} \mathrm{~L}^{-1}$. Other factors, such as $\mathrm{Na}_{2} \mathrm{HPO}_{4}, \mathrm{KH}_{2} \mathrm{PO}_{4}, \mathrm{NaCl}$, and $\mathrm{MgSO}_{4}$, were also set to concentration gradients of 6.5-10.5, $1.0-5,0.1-2.0$, and $0.1-2.0 \mathrm{~g} \mathrm{~L}^{-1}$, respectively. The antimicrobial activity of supernatant was then detected to find the optimal concentration. All the experiments were done in triplicate.

\subsection{Screening of Significant Variables Using PB Design}

The relative significance of six variables, namely, sucrose, $\mathrm{Na}_{2} \mathrm{HPO}_{4}, \mathrm{KH}_{2} \mathrm{PO}_{4}, \mathrm{NH}_{4} \mathrm{Cl}, \mathrm{MgSO}_{4}$, and $\mathrm{NaCl}$, were investigated using the PB design (Tables 5 and 6) to determine the key factors significantly affecting the antibacterial activity of GBacillus-9. Six variables of medium composition were tested at low (-1) and high (+1) levels on the basis of the PB matrix design [49]. The PB experimental design was based on the first-order model (5):

$$
Y=\beta_{0}+\Sigma \beta_{i} x_{i}
$$

where $Y$ is the predicted response, $\beta_{0}$ is the model intercept, $\beta_{i}$ is the linear coefficient, and $x_{i}$ is the level of the independent variable. According to the $P$-value of the experimental results, the main factors affecting the diameter of the inhibition zone can be obtained. The factors with significant $(p<0.05)$ influence on the experimental results were selected for the response surface optimization. 
Table 5. Plackett-Burman (PB) factor level design.

\begin{tabular}{cccc}
\hline & \multirow{2}{*}{ Factor } & & \multicolumn{2}{c}{ Level $\left.\mathbf{g ~ L}^{\mathbf{- 1}}\right)$} \\
\cline { 3 - 4 } & & $\mathbf{- 1}$ & $\mathbf{+ 1}$ \\
\hline $\mathrm{A}$ & sucrose $_{\mathrm{1}}$ & 20.0 & 40.0 \\
$\mathrm{~B}$ & $\mathrm{KH}_{2} \mathrm{PO}_{4}$ & 2.0 & 4.0 \\
$\mathrm{C}$ & $\mathrm{Na}_{2} \mathrm{HPO}_{4}$ & 7.5 & 9.5 \\
$\mathrm{D}$ & $\mathrm{NH}_{4} \mathrm{Cl}$ & 0.5 & 1.5 \\
$\mathrm{E}$ & $\mathrm{NaCl}_{\mathrm{Ca}}$ & 0.25 & 0.75 \\
$\mathrm{~F}$ & $\mathrm{MgSO}_{4}$ & 0.25 & 0.75 \\
$\mathrm{G}$ & blank & 0.0 & 0.0 \\
\hline
\end{tabular}

Table 6. PB experimental design and results.

\begin{tabular}{ccccccccc}
\hline $\begin{array}{c}\text { Experiment } \\
\text { Group }\end{array}$ & A & B & C & D & E & F & $\begin{array}{c}\text { TG1 Inhibition Zone } \\
\text { Diameter (cm) }\end{array}$ & $\begin{array}{c}\text { BS168 Inhibition } \\
\text { Zone Diameter (cm) }\end{array}$ \\
\hline 1 & -1 & 1 & -1 & -1 & -1 & 1 & 1.000 & 1.150 \\
2 & 1 & -1 & 1 & 1 & -1 & 1 & 1.500 & 1.620 \\
3 & 1 & 1 & -1 & 1 & 1 & -1 & 1.700 & 1.650 \\
4 & -1 & -1 & 1 & 1 & 1 & -1 & 1.400 & 1.000 \\
5 & -1 & -1 & -1 & -1 & -1 & -1 & 1.100 & 1.300 \\
6 & -1 & -1 & -1 & 1 & 1 & 1 & 1.200 & 1.200 \\
7 & -1 & -1 & -1 & -1 & 1 & 1 & 1.150 & 1.650 \\
8 & 1 & 1 & -1 & 1 & -1 & -1 & 1.650 & 1.200 \\
9 & 0 & 0 & 0 & 0 & 0 & 0 & 1.500 & 1.300 \\
10 & -1 & -1 & 1 & -1 & -1 & -1 & 1.500 & 1.500 \\
11 & 1 & 1 & 1 & 1 & -1 & 1 & 1.300 & 1.600 \\
12 & 1 & 1 & 1 & -1 & 1 & -1 & 1.200 & \\
13 & 1 & 1 & 1 & -1 & 1 & 1 & 1.400 & \\
\hline
\end{tabular}

\subsection{Optimization of Significant Variables Using CCD}

The CCD experiment can achieve the sequentiality of the test and better fits the corresponding surface because, in the CCD test design process, many points are beyond the original level $[15,16,50]$. A CCD with five coded levels was used for locating the optimum conditions of sucrose, $\mathrm{NH}_{4} \mathrm{Cl}$, and $\mathrm{MgSO}_{4}$ to find the optimal cultivation conditions for GBacillus-9. For the three factors, this trial was essentially a full 23 factorial design with six axial points $(a=1.68)$ and six replications of the center points, resulting in a total number of 20 experiments (Tables 7 and 8). Mathematical models describing the relationship among the process variables in terms of their linear, quadratic, and interactive effects used were described using a second-order polynomial equation presented in Equation (6):

$$
Y=\beta_{0}+\Sigma \beta_{\mathrm{i}} \mathrm{x}_{\mathrm{i}}+\Sigma \beta_{\mathrm{ii}} \mathrm{x}_{\mathrm{i}}^{2}+\Sigma \beta_{\mathrm{ij}} \mathrm{x}_{\mathrm{i}} \mathrm{x}_{\mathrm{j}}
$$

where $\mathrm{Y}$ is the predicted response, $\beta_{0}$ is the intercept term, $\beta_{\mathrm{i}}$ represents the linear coefficients, $\beta_{\mathrm{ii}}$ represents the quadratic coefficients, $\beta_{\mathrm{ij}}$ represents the interactive coefficients, and $x_{\mathrm{i}}$ and $x_{j}$ are the coded independent variables $[19,51]$. Other media concentrations remained at $8.5,3$, and $0.5 \mathrm{~g} \mathrm{~L}^{-1}$ for $\mathrm{Na}_{2} \mathrm{HPO}_{4}, \mathrm{KH}_{2} \mathrm{PO}_{4}$ and $\mathrm{NaCl}$, respectively.

Table 7. CCD experimental design.

\begin{tabular}{ccccccc}
\hline \multicolumn{2}{c}{ Factors } & \multicolumn{5}{c}{ Levels of Variables $\left(\mathrm{g} \mathrm{L} \mathrm{L}^{-\mathbf{1}}\right)$} \\
\hline & & -1.68 & -1 & 0 & +1 & 1.68 \\
$\mathrm{~A}$ & sucrose & 13.200 & 20.000 & 30.000 & 40.000 & 46.800 \\
$\mathrm{~B}$ & $\mathrm{NH}_{4} \mathrm{Cl}$ & 0.160 & 0.500 & 1.000 & 1.500 & 1.840 \\
$\mathrm{C}$ & $\mathrm{MgSO}_{4}$ & 0.080 & 0.250 & 0.500 & 0.750 & 0.920 \\
\hline
\end{tabular}


Table 8. Results of CCD experimental design.

\begin{tabular}{|c|c|c|c|c|c|c|c|}
\hline \multirow{2}{*}{$\begin{array}{c}\text { Test } \\
\text { Number }\end{array}$} & \multirow{2}{*}{ A } & \multirow{2}{*}{ B } & \multirow{2}{*}{ C } & \multicolumn{2}{|c|}{ TG1 Inhibition Zone Diameter (cm) } & \multicolumn{2}{|c|}{ BS168 Inhibition Zone Diameter (cm) } \\
\hline & & & & Actual Value & Predicted Value & Actual Value & Predicted Value \\
\hline 1 & 0.00 & 0.00 & 0.00 & 1.43 & 1.43 & 1.42 & 1.44 \\
\hline 2 & -1.00 & 1.00 & 1.00 & 1.27 & 1.26 & 1.25 & 1.25 \\
\hline 3 & 0.00 & 0.00 & 0.00 & 1.43 & 1.43 & 1.43 & 1.44 \\
\hline 4 & 1.00 & 1.00 & 1.00 & 1.45 & 1.5 & 1.44 & 1.47 \\
\hline 5 & -1.68 & 0.00 & 0.00 & 1.3 & 1.31 & 1.28 & 1.29 \\
\hline 6 & 0.00 & -1.68 & 0.00 & 1.25 & 1.26 & 1.27 & 1.28 \\
\hline 7 & 0.00 & 0.00 & 0.00 & 1.42 & 1.43 & 1.44 & 1.44 \\
\hline 8 & 0.00 & 0.00 & 0.00 & 1.43 & 1.43 & 1.46 & 1.44 \\
\hline 9 & -1.00 & -1.00 & -1.00 & 1.31 & 1.28 & 1.32 & 1.30 \\
\hline 10 & 1.00 & -1.00 & 1.00 & 1.37 & 1.36 & 1.38 & 1.37 \\
\hline 11 & -1.00 & -1.00 & 1.00 & 1.25 & 1.26 & 1.24 & 1.25 \\
\hline 12 & 0.00 & 0.00 & 1.68 & 1.27 & 1.26 & 1.29 & 1.28 \\
\hline 13 & 0.00 & 0.00 & 0.00 & 1.43 & 1.43 & 1.48 & 1.44 \\
\hline 14 & 0.00 & 0.00 & -1.68 & 1.50 & 1.49 & 1.47 & 1.48 \\
\hline 15 & 0.00 & 1.68 & 0.00 & 1.52 & 1.49 & 1.48 & 1.46 \\
\hline 16 & 1.68 & 0.00 & 0.00 & 1.72 & 1.68 & 1.62 & 1.60 \\
\hline 17 & 1.00 & 1.00 & -1.00 & 1.75 & 1.76 & 1.66 & 1.66 \\
\hline 18 & 1.00 & -1.00 & -1.00 & 1.45 & 1.48 & 1.44 & 1.45 \\
\hline 19 & -1.00 & 1.00 & -1.00 & 1.38 & 1.41 & 1.4 & 1.41 \\
\hline 20 & 0.00 & 0.00 & 0.00 & 1.44 & 1.43 & 1.43 & 1.44 \\
\hline
\end{tabular}

\subsection{Optimization of Fermentation Conditions}

On the basis of the optimized medium using the CCD experiment, a shake flask was used to optimize the fermentation conditions ( $\mathrm{pH}$, rotation speed, temperature, inoculum size, and time). For $\mathrm{pH}, \mathrm{M} 9$ medium was dispensed into $250 \mathrm{~mL}$ flasks (100 mL per flask). The flasks were autoclaved at $121{ }^{\circ} \mathrm{C}$ for $20 \mathrm{~min}$. After cooling, each flask was inoculated with GBacillus-9 and incubated at different $\mathrm{pH}$ values (6-8) for $12 \mathrm{~h}$. All the experiments were done in triplicate. For the other parameters, the same M9 medium was employed, but the medium was adjusted to different values. A total of 100 $\mathrm{mL}$ in each treatment was dispensed into the $250 \mathrm{~mL}$ flask and replicated thrice.

\subsection{Preparation and Property Analysis}

A small-scale fermentation experiment by using a $20 \mathrm{~L}$ fermenter was carried out to verify the optimal medium formula and fermentation conditions. The antibacterial activity of the fermentation broth was determined, which laid a foundation for preparing the bacterial preparation.

Author Contributions: Conceptualization, H.S. and Z.L.; methodology, G.L. and W.Z.; validation, W.Z., L.W., G.L., H.X. and R.X.; formal analysis, W.Z. R.X. and G.L.; resources, Z.L.; writing-original draft preparation, W.Z.; writing-review and editing, H.S.; visualization, H.S. and H.Q.; supervision, H.S.; funding acquisition, H.S. All authors have read and agreed to the published version of the manuscript.

Funding: This research was funded by Zhejiang Province Basic Public Welfare Technology Research Project, China, grant number: LGN19C170007.

Conflicts of Interest: The authors declare no conflict of interest.

\section{References}

1. Czaplewski, L.; Bax, R.; Clokie, M.; Dawson, M.; Fairhead, H.; Fischetti, V.A.; Foster, S.; Gilmore, B.F.; Hancock, R.E.; Harper, D.; et al. Alternatives to antibiotics-a pipeline portfolio review. Lancet. Infect. Dis. 2016, 16, 239-251. [CrossRef]

2. Ng, T.B.; Cheung, R.C.F.; Wong, J.H.; Bekhit, A.A.; Bekhit, A.E.D. Antibacterial products of marine organisms. Appl. Microbiol. Biotech. 2015, 99, 4145-4173. [CrossRef] [PubMed]

3. Tanaka, K.; Fukuda, M.; Amaki, Y.; Sakaguchi, T.; Inai, K.; Ishihara, A.; Nakajima, H. Importance of prumycin produced by Bacillus amyloliquefaciens SD-32 in biocontrol against cucumber powdery mildew disease. Pest Manag. Sci. 2017, 73, 2419-2428. [CrossRef] [PubMed] 
4. Regmi, S.; Choi, Y.H.; Choi, Y.S.; Kim, M.R.; Yoo, J.C. Antimicrobial peptide isolated from Bacillus amyloliquefaciens K14 revitalizes its use in combinatorial drug therapy. Folia Microbiol. 2017, 62, 127-138. [CrossRef]

5. Kumar, S.; Haq, I.; Prakash, J.; Singh, S.K.; Mishra, S.; Raj, A. Purification, characterization and thermostability improvement of xylanase from Bacillus amyloliquefaciens and its application in pre-bleaching of kraft pulp. 3 Biotech. 2017, 7, 20. [CrossRef]

6. Farhat-Khemakhem, A.; Blibech, M.; Boukhris, I.; Makni, M.; Chouayekh, H. Assessment of the potential of the multi-enzyme producer Bacillus amyloliquefaciens US573 as alternative feed additive. J. Sci. Food Agric. 2018, 98, 1208-1215. [CrossRef]

7. Kim, P.I.; Chung, K.C. Production of an antifungal protein for control of Colletotrichum lagenarium by Bacillus amyloliquefaciens MET0908. FEMS Microbiol. Lett. 2004, 234, 177-183. [CrossRef]

8. Arrebola, E.; Jacobs, R.; Korsten, L. Iturin A is the principal inhibitor in the biocontrol activity of Bacillus amyloliquefaciens PPCB004 against postharvest fungal pathogens. J. Appl. Microbiol. 2010, 108, 386-395. [CrossRef]

9. Bindiya, E.S.; Tina, K.J.; Raghul, S.S.; Bhat, S.G. Characterization of Deep Sea Fish Gut Bacteria with Antagonistic Potential, from Centroscyllium fabricii (Deep Sea Shark). Probiotics Antimicrob. Proteins 2015, 7, 157-163. [CrossRef]

10. Ringo, E.; Bendiksen, H.R.; Wesmajervi, M.S.; Olsen, R.E.; Jansen, P.A.; Mikkelsen, H. Lactic acid bacteria associated with the digestive tract of Atlantic salmon (Salmo salar L.). J. Appl. Microbiol. 2000, 89, 317-322. [CrossRef]

11. Makridis, P.; Martins, S.; Tsalavouta, M.; Dionisio, L.C.; Dinis, M.T. Antimicrobial activity in bacteria isolated from Senegalese sole, Solea senegalensis, fed with natural prey. Aquacul. Res. 2005, 36, 1619-1627. [CrossRef]

12. Wu, J.; Xu, G.Q.; Jin, Y.Y.; Sun, C.; Zhou, L.; Lin, G.D.; Xu, R.; Wei, L.; Fei, H.; Wang, D.; et al. Isolation and characterization of Bacillus sp GFP-2, a novel Bacillus strain with antimicrobial activities, from Whitespotted bamboo shark intestine. Amb Express 2018, 8, 84. [CrossRef] [PubMed]

13. Fei, H.; Lin, G.D.; Zheng, C.C.; Huang, M.M.; Qian, S.C.; Wu, Z.J.; Sun, C.; Shi, Z.G.; Li, J.Y.; Han, B.N. Effects of Bacillus amyloliquefaciens and Yarrowia lipolytica lipase 2 on immunology and growth performance of Hybrid sturgeon. Fish Shellfish Immunol. 2018, 82, 250-257. [CrossRef] [PubMed]

14. Zheng, C.C.; Cai, X.Y.; Huang, M.M.; Mkingule, I.; Sun, C.; Qian, S.C.; Wu, Z.J.; Han, B.N.; Fei, H. Effect of biological additives on Japanese eel (Anguilla japonica) growth performance, digestive enzymes activity and immunology. Fish Shellfish Immunol. 2019, 84, 704-710. [CrossRef] [PubMed]

15. Box, G.E.P.; Wilson, K.B.J.R. On the Experimental Attainment of Optimum Conditions. J. R. Stat. Soc.: Ser. B (Method) 1951, 13, 1-38. [CrossRef]

16. Gupta, N.; Sahai, V.; Gupta, R. Alkaline lipase from a novel strain Burkholderia multivorans: Statistical medium optimization and production in a bioreactor. Process Biochem. 2007, 42, 518-526. [CrossRef]

17. Zhou, W.W.; He, Y.L.; Niu, T.G.; Zhong, J.J. Optimization of fermentation conditions for production of anti-TMV extracellular ribonuclease by Bacillus cereus using response surface methodology. Bioprocess Biosyst. Eng. 2010, 33, 657-663. [CrossRef]

18. Blanco, M.; Vazquez, J.A.; Perez-Martin, R.I.; C, G.S. Collagen Extraction Optimization from the Skin of the Small-Spotted Catshark (S. canicula) by Response Surface Methodology. Mar. Drugs 2019, 17, 40. [CrossRef]

19. Montero-Lobato, Z.; Ramos-Merchante, A.; Fuentes, J.L.; Sayago, A.; Fernandez-Recamales, A.; Martinez-Espinosa, R.M.; Vega, J.M.; Vilchez, C.; Garbayo, I. Optimization of Growth and Carotenoid Production by Haloferax mediterranei Using Response Surface Methodology. Mar. Drugs 2018, 16, 372. [CrossRef]

20. Lin, E.S.; Wang, C.-C.; Sung, S.-C. Cultivating conditions influence lipase production by the edible Basidiomycete Antrodia cinnamomea in submerged culture. Enzyme Microbial Technol. 2006, 39, 98-102. [CrossRef]

21. Raza, W.; Makeen, K.; Wang, Y.; Xu, Y.C.; Shen, Q.R. Optimization, purification, characterization and antioxidant activity of an extracellular polysaccharide produced by Paenibacillus polymyxa SQR-21. Bioresour. Technol. 2011, 102, 6095-6103. [CrossRef] [PubMed]

22. He, S.; Wang, H.; Wu, B.; Zhou, H.; Zhu, P.; Yang, R.; Yan, X. Response surface methodology optimization of fermentation conditions for rapid and efficient accumulation of macrolactin A by marine Bacillus amyloliquefaciens ESB-2. Molecules 2012, 18, 408-417. [CrossRef] [PubMed] 
23. Muralidhar, R.V.; Chirumamila, R.R.; Marchant, R.; Nigam, P. A response surface approach for the comparison of lipase production by Candida cylindracea using two different carbon sources. Biochem. Eng. J. 2001, 9, 17-23. [CrossRef]

24. Xu, H.; Sun, L.-P.; Shi, Y.-Z.; Wu, Y.-H.; Zhang, B.; Zhao, D.-Q. Optimization of cultivation conditions for extracellular polysaccharide and mycelium biomass by Morchella esculenta As51620. Biochem. Eng. J. 2008, 39, 66-73. [CrossRef]

25. Simmons, T.L.; Coates, R.C.; Clark, B.R.; Engene, N.; Gonzalez, D.; Esquenazi, E.; Dorrestein, P.C.; Gerwick, W.H. Biosynthetic origin of natural products isolated from marine microorganism-invertebrate assemblages. Proc. Natl. Acad. Sci. USA 2008, 105, 4587-4594. [CrossRef] [PubMed]

26. Parkes, R.J.; Cragg, B.A.; Bale, S.J.; Getlifff, J.M.; Goodman, K.; Rochelle, P.A.; Fry, J.C.; Weightman, A.J.; Harvey, S.M. Deep bacterial biosphere in Pacific Ocean sediments. Nature 1994, 371, 410-413. [CrossRef]

27. Ganz, T. Defensins: Antimicrobial peptides of innate immunity. Nat. Rev. Immunol. 2003, 3, 710-720. [CrossRef]

28. Tam, J.P.; Wu, C.; Yang, J.L. Membranolytic selectivity of cystine-stabilized cyclic protegrins. Eur. J. Biochem. 2000, 267, 3289-3300. [CrossRef]

29. Yeaman, M.R.; Yount, N.Y. Mechanisms of antimicrobial peptide action and resistance. Pharmacol. Rev. 2003, 55, 27-55. [CrossRef]

30. Gong, W.; Wang, J.; Chen, Z.; Xia, B.; Lu, G. Solution structure of LCI, a novel antimicrobial peptide from Bacillus subtilis. Biochemistry 2011, 50, 3621-3627. [CrossRef]

31. Mizumoto, S.; Shoda, M. Medium optimization of antifungal lipopeptide, iturin A, production by Bacillus subtilis in solid-state fermentation by response surface methodology. Appl. Microbiol. Biotechnol. 2007, 76, 101-108. [CrossRef] [PubMed]

32. Zhang, W.G.; Zhang, P.L.; Sun, H.; Chen, M.Z.; Lu, S.; Li, P.F. Effects of various organic carbon sources on the growth and biochemical composition of Chlorella pyrenoidosa. Bioresour. Technol. 2014, 173, 52-58. [CrossRef] [PubMed]

33. Li, P.T.; Hsiao, W.L.; Yu, R.C.; Chou, C.C. Effect of heat shock on the fatty acid and protein profiles of Cronobacter sakazakii BCRC 13988 as well as its growth and survival in the presence of various carbon, nitrogen sources and disinfectants. Food Microbiol. 2013, 36, 142-148. [CrossRef] [PubMed]

34. Pervez, M.R.; Bhadange, D.G.; Thakare, P.V.; Mussadiq, M. Isolation, Sreening and Optimization of Submerged Culture Conditions for Mycelial Biomass Production with Enhanced Antibacterial Activity of the Fungus Myrothecium Spp. Mrp001 against Multi Drug Resistant Pathogens. J. Microb. Biotechnol. Food 2015, 5, $23-28$. [CrossRef]

35. Kim, H.O.; Lim, J.M.; Joo, J.H.; Kim, S.W.; Hwang, H.J.; Choi, J.W.; Yun, J.W. Optimization of submerged culture condition for the production of mycelial biomass and exopolysaccharides by Agrocybe cylindracea. Bioresour. Technol. 2005, 96, 1175-1182. [CrossRef]

36. Guzun, A.S.; Stroescu, M.; Jinga, S.I.; Voicu, G.; Grumezescu, A.M.; Holban, A.M. Plackett-Burman experimental design for bacterial cellulose-silica composites synthesis. Mater. Sci. Eng. C 2014, 42, 280-288. [CrossRef]

37. Li, Y.; Liu, Z.; Cui, F.; Liu, Z.; Zhao, H. Application of Plackett-Burman experimental design and Doehlert design to evaluate nutritional requirements for xylanase production by Alternaria mali ND-16. Appl. Microbiol. Biotechnol. 2007, 77, 285-291. [CrossRef]

38. Torchio, F.; Giacosa, S.; Vilanova, M. Use of response surface methodology for the assessment of changes in the volatile composition of Moscato bianco (Vitis vinifera L.) grape berries during ripening. Food Chem. 2016, 212, 576-584. [CrossRef]

39. Desmond, C.R.; Ross, R.P.; O'Callaghan, E.O.; Fitzgerald, G.; Stanton, C. Improved survival of Lactobacillus paracasei NFBC 338 in spray-dried powders containing gum acacia. J. Appl. Microbiol. 2002, 93, 1003-1011. [CrossRef]

40. Ushida, K.; Sakata, T. Effect of ph on oligosaccharide fermentation by porcine cecal digesta. Anim. Sci. Technol. (Jpn.) 1998, 69, 100-107. [CrossRef]

41. Lacroix, C.; Leduy, A.; Noel, G.; Choplin, L. Effect of $\mathrm{pH}$ on the batch fermentation of pullulan from sucrose medium. Biotechnol. Bioeng. 1985, 27, 202-207. [CrossRef] [PubMed]

42. Fang, Q.H.; Zhong, J.J. Effect of initial ph on production of ganoderic acid and polysaccharide by submerged fermentation of ganoderma lucidum. Process Biochem. 2002, 37, 769-774. [CrossRef] 
43. Gibbons, W.R.; Westby, C.A. Effects of inoculum size on solid-phase fermentation of fodder beets for fuel ethanol production. Appl. Environ. Microbiol. 1986, 52, 960-962. [CrossRef] [PubMed]

44. Castillo, M.; Lucey, J.A.; Payne, F.A. The effect of temperature and inoculum concentration on rheological and light scatter properties of milk coagulated by a combination of bacterial fermentation and chymosin. Int. Dairy J. 2006, 16, 131-146. [CrossRef]

45. Hu, H.; Shi, Y.; Liao, K.; Ma, H.; Xu, K.; Ren, H. Effect of temperature on the characterization of soluble microbial products in activated sludge system with special emphasis on dissolved organic nitrogen. Water Res. 2019, 162, 87-94. [CrossRef]

46. Ray, A.K.; Bairagi, A.; Ghosh, K.S.; Sen, S.K. Optimization of fermentation conditions for cellulase production by Bacillus subtilis CY5 and Bacillus circulans TP3 isolated from fish gut. Acta Ichthyologica et Piscatoria 2007, 37, 47-53. [CrossRef]

47. Chunmei, L.; He, J.; Hui, C.; Wang, H.; Han, X.; Qi, W. Optimization of Fermentation Conditions for Producing Neutral Cellulase from a High-yield Bacillus megaterium Genetic Engineering Bacteria. J. Agric. Biotechnol. 2011, 19, 557-564. [CrossRef]

48. Catarino, M.D.; Silva, A.M.S.; Mateus, N.; Cardoso, S.M. Optimization of Phlorotannins Extraction from Fucus vesiculosus and Evaluation of Their Potential to Prevent Metabolic Disorders. Mar. Drugs 2019, 17, 162. [CrossRef]

49. Burman, R.L.P.P. The Design of Optimum Multifactorial Experiments. Biometrika 1946, 33, 305-325. [CrossRef]

50. Liu, J.; Wen, S.; Liu, D.; Lv, M.; Liu, L. Response surface methodology for optimization of copper leaching from a low-grade flotation middling. Mining Metallurgy Exploration 2011, 28, 139-145. [CrossRef]

51. Song, X.Y.; Xie, S.T.; Chen, X.L.; Sun, C.Y.; Shi, M.; Zhang, Y.Z. Solid-state fermentation for Trichokonins production from Trichoderma koningii SMF2 and preparative purification of Trichokonin VI by a simple protocol. J. Biotechnol. 2007, 131, 209-215. [CrossRef] [PubMed]

(C) 2020 by the authors. Licensee MDPI, Basel, Switzerland. This article is an open access article distributed under the terms and conditions of the Creative Commons Attribution (CC BY) license (http://creativecommons.org/licenses/by/4.0/). 